\title{
CHIRAL BINAPHTHALENES BEARING TWO PYRIDINE LIGANDS ATTACHED VIA ACETYLENE SPACERS. SYNTHESIS AND COORDINATION STUDY
}

\author{
Peter KASÁK ${ }^{a, b}$, Henrich BratH ${ }^{a 1}$, Katarína KRASCSENICSOVÁ-POLÁKOVÁ ${ }^{a}$, \\ Anna KiCKOvÁa ${ }^{a 2}$, Natalia Moldovan ${ }^{a 3}$ and Martin PUTAlA ${ }^{a 4, *}$ \\ ${ }^{a}$ Department of Organic Chemistry, Faculty of Natural Sciences, Comenius University, \\ Mlynská dolina, 84215 Bratislava, Slovak Republic; e-mail: ${ }^{1}$ henrichbrath@hotmail.com, \\ ${ }^{2}$ kickova@fns.uniba.sk, ${ }^{3}$ moldovan@fns.uniba.sk, ${ }^{4}$ putala@fns.uniba.sk \\ ${ }^{b}$ Polymer Institute of the Slovak Academy of Sciences, Dúbravská cesta 9, 84236 Bratislava, \\ Slovak Republic; e-mail: peter.kasak@savba.sk
}

Received May 21, 2007

Accepted June 28, 2007

Dedicated to Professor Štefan Toma on the occasion of his 70th birthday.

An effective methodology has been developed for the synthesis of enantiopure 2,2'-dialkynylated 1,1'-binaphthalene derivatives. Enantiopure 2,2'-diiodo-1,1'-binaphthalene (10) provided 2,2'-diethynyl-1,1'-binaphthalene (16) in the Negishi alkynylation supported by microwave irradiation in a very good yield with conservation of stereochemical information. The Stephen-Castro alkynylation of $\mathbf{1 0}$ afforded products in lower yields; however, in stereoconservative manner as well. Terminal diacetylene $\mathbf{1 6}$ served as precursor in the Sonogashira cross-coupling reaction to give new bispyridine derivatives 7-9 as potential ligands in moderate to high yields. Coordination of bispyridines with $\mathrm{Zn}^{2+}$ and $\mathrm{Ag}^{+}$ions was observed by NMR and CD spectroscopy. The coordination ability of bis(2-pyridylethynyl) derivative $\mathbf{7}$ to palladium cation was determined by $\mathrm{X}$-ray structure analysis.

Keywords: Sonogashira reaction; Alkynylations; Bispyridines; Binaphthalenes; $\mathrm{C}_{2}$-Symmetric ligands; Cross-coupling reactions; Palladium; Alkynes; Helicenes; Biaryls.

Axial chirality as a unique stereochemical property of axially chiral $1,1^{\prime}$-binaphthalene derivatives substituted at the position 2 and $2^{\prime}$ plays a crucial role in their broad application in stereosel ective synthesis ${ }^{1}$, in materials science ${ }^{2}$, in the separation and recognition of chiral compounds ${ }^{3}$. Substitution reactions, in particular cross-coupling reactions, at both positions 2 and 2 ' are critical for conservation of stereochemical information in the course of preparation of such derivatives ${ }^{4-7}$. Specialty of the cross-coupling reactions (or any substitutions) at the positions 2 and 2 ' consist in substan- 
tial steric hindrance (bulky 2-substituted 1-naphthyl group in the position adjacent to the reaction center) and the risk of racemization during the reaction, since these reactions take place in the positions where mutual nonbonding interactions between groups (replaced in the course of the reaction) is decisive for configurational stability of these derivatives ${ }^{5-7}$.

Bidendate non racemic $\mathrm{C}_{2}$-symmetric ligands with $\mathrm{N}, \mathrm{N}$-donor atoms were used successfully in stereoselective synthesis and in supramolecular chemistry as ligands (for example oxazolines $\mathbf{1}^{8}$, sermicorrines $\mathbf{2}^{9}$, bisaziridines $3^{10}$, bipyridines $\mathbf{4}^{11}$, including binaphthalene based ligands 5 and 6 (Fig. 1) 12,13. Those based on 2,2'-diaryl-1,1'-binaphthalenes have strained chiral pocket ${ }^{13}$. Therefore it would be interesting to move far away donor groups from binaphthalene keeping stereochemical information via linking with rigid ethynediyl spacer 7-9.

Racemic 2,2'-bis(arylethynyl)-1,1'-binaphthalenes were prepared by alkynylation with copper acetylide ${ }^{14}$ and in nonracemic form via a multistep synthesis including build-up of the ethynyl group starting from 1,1'-binaphthalene-2,2'-dicarbaldehyde ${ }^{15}$ followed by attachment of aryl groups via the Sonogashira reaction.

We aimed to elaborate an effective approach to nonracemic bis(arylethynyl) derivatives 7-9 with potential application either in stereoselective synthesis (as new chiral ligands), supramolecular chemistry (as chiral building blocks), or in materials science (chiral compounds with specific optical or electronic properties). Being encouraged by the efficient Negishi $2,2^{\prime}$-dial kylation ${ }^{5}$ and diarylation ${ }^{6,16}$ of 2,2'-disubstituted 1, $1^{\prime}$-binaphtha-

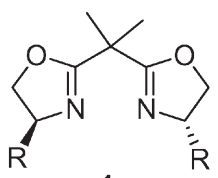

1

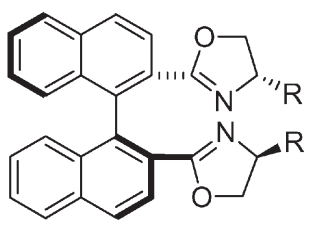

5

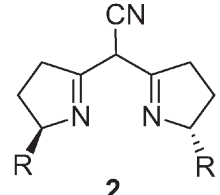

2

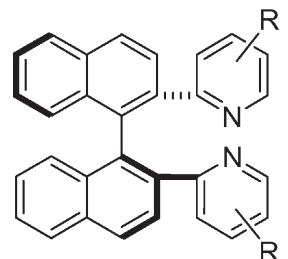

6

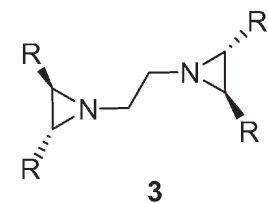

3

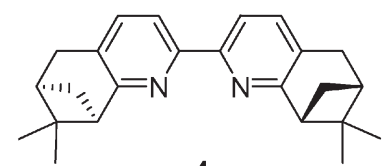

4

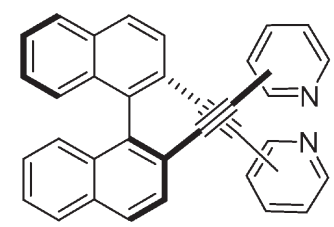

7: 2-pyridyl

8: 3-pyridyl

9: 4-pyridyl

FIG. 1

Selected examples of bidendate $\mathrm{N}, \mathrm{N}$-coordinating $\mathrm{C}_{2}$-symmetric ligands 
lenes, in particular diiodide 10, we concentrated our effort on the use of cross-coupling reactions.

\section{RESULTS AND DISCUSSION}

Dialkynylation of 2,2'-Disubstituted 1,1'-Binaphthalenes

In agreement with the reported application of the Sonogashira reaction conditions in the reaction of racemic $\mathbf{1 0}$ with phenylacetylene in the presence of Cul and base, helical product $\mathbf{1 1}$ as an outcome of tandem reaction was formed in $86 \%$ yield ${ }^{14}$. This seems to be a general course of the reaction of diiodide $\mathbf{1 0}$ with terminal alkynes under the Sonogashira conditions since an analogous result was obtained also with (trimethylsilyl)ethyne; it afforded $\mathbf{1 2}$ in high $82 \%$ yield (Scheme 1).

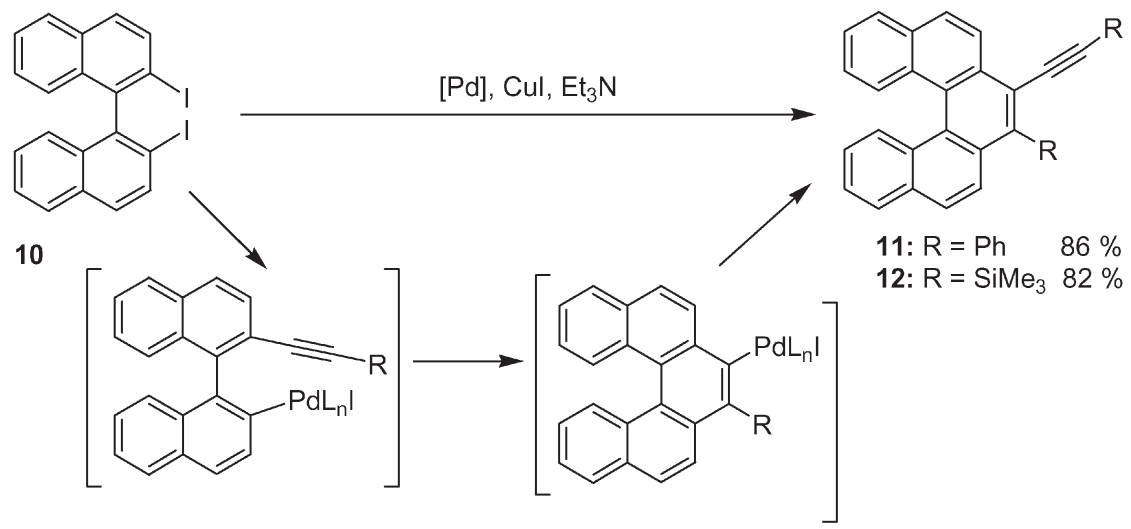

SCHEME 1

Synthesis of $\mathbf{1 3}$ in racemic form was accomplished via the Stephen-Castro protocol in $31 \%$ yiel $\mathrm{d}^{14}$. Using enantiopure (R)-10, we found that this reaction proceeded stereoconservatively at $120{ }^{\circ} \mathrm{C}$, affording the desired product in a higher, $40 \%$ yield (Table I, entry 1 ). With the aim to prepare universal precursor with ethynyl spacers and improve yields of the reaction, attempts to prepare copper (trimethylsilyl)acetylide were accompanied by decomposition and formation of polymerized side products (Table I, entry 2). Therefore we tried to obtain dialkynylated products via crosscoupling reaction.

The reactions with less reactive dielectrophile, bistriflate 14, were not successful under the Kumada or Negishi reaction conditions with various 
catalytic systems (5-20 mole \% of [Pd(PPh $\left.)_{4}\right],\left[\mathrm{NiCl}_{2}(\mathrm{dppe})\right],\left[\mathrm{NiCl}_{2}\left(\mathrm{PPh}_{3}\right)_{2}\right]$, $\left.\left[\mathrm{PdCl}_{2}\left(\mathrm{PPh}_{3}\right)_{2}\right]\right)$ and in different solvents (diethyl ether, THF).

Then, the attempts were focused on application of more reactive diiodide 10. No reaction was observed with the in situ formed zinc reagent from phenylacetylene, $\mathrm{ZnCl}_{2}$ and $\mathrm{Et}_{3} \mathrm{~N}^{17}$ (Table I, entry 3). The reaction with (phenylethynyl)zinc chloride, prepared via lithiation and transmetallation with zinc chloride, required excess of zinc reagent (optimally 3 equiv. for each Ar-I bond) in THF at reflux to obtain dialkynylated product $\mathbf{1 3}$ in

TABLE I

Preparation of nonracemic (R)-2,2'-dialkynyl-1,1'-binaphthalenes (13 and 15) from binaphthalene dielectrophiles

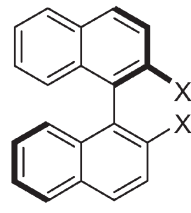

10: $X=1$

14: $X=$ OTf

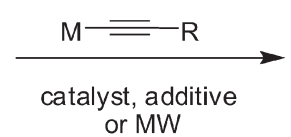

$\mathrm{M}=\mathrm{Cu}, \mathrm{ZnCl}, \mathrm{MgBr}$

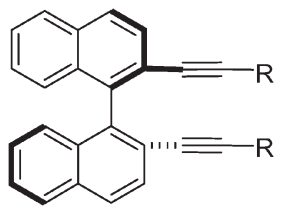

13: $\mathrm{R}=\mathrm{Ph}$

15: $\mathrm{R}=\mathrm{SiMe}_{3}$

\section{Entry $\quad X \quad M C \equiv C R$ (equivalents)}

Catalyst, additive
Heating Product $\begin{array}{ll}\text { Time } & \begin{array}{l}\text { Yield } \\ \mathrm{h}\end{array} \\ \%\end{array}$
40

15

13

72

13

$0.6^{c}$

66

13

0.05

90

15

$3^{c}$

70

$15 \quad 0.05$

81

\footnotetext{
${ }^{a}$ Isolated yield. ${ }^{b}$ The zinc reagent prepared in the presence of amine. ${ }^{c}$ Time required for complete conversion of $\mathbf{1 0}{ }^{d}$ Ref. $^{16}$
} 
good yield (66\%, Table I, entry 4). Trimethylsilyl-protected derivative 15 was obtained according to this protocol in $70 \%$ yield (Table I, entry 6 ). Under the Negishi reaction conditions, helical side products $\mathbf{1 1}$ and $\mathbf{1 2}$ were formed only in small amounts (3-5\%).

Considering that microwave irradiation has a positive effect on shortening the reaction time and yield of cross-coupling reactions ${ }^{16,18}$, microwave irradiation was applied to the above Negishi dialkynylations. The reactions under microwave irradiation at $120^{\circ} \mathrm{C}$ yielding 13 and 15 proceeded to full conversion in a shorter time ( 3 min compared with 40 min for 13 and $3 \mathrm{~h}$ for 15) and improved yields to 90 and 81\%, respectively (Table I, entries 5 and 7$)^{16}$. The reaction under both the conditions (classical heating or microwave irradiation) starting from enantiomerically pure diiodide (R)-10 ( $99 \%$ ee, HPLC) proceeded stereoconservatively (99\% ee, HPLC).

The protecting trimethylsilyl group was removed with $\mathrm{K}_{2} \mathrm{CO}_{3}$ in a THF-M eOH mixture (1:1) to give (R)-16 (99\% ee, HPLC) in very good yield $91 \%$ (Scheme 2) as general precursor for the preparation of 2,2'-bis(arylethynyl) derivatives.

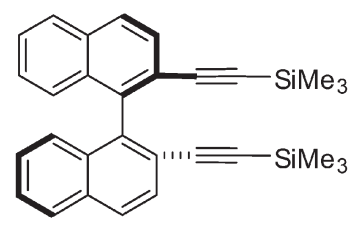

$(R S)$ - and $(R)-15$

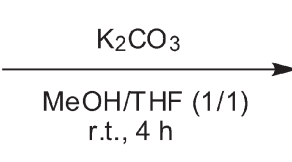

$(R S)-$ and $(R)-16,91 \%$

SCHEME 2

\section{Preparation of 2,2'-Bis(pyridylethynyl)-1,1'-binaphthalenes}

After preparation of nonracemic diethynyl derivative $\mathbf{1 6}$ we focused on its arylation. Bis(arylethynyl) derivatives with a donor atom in the molecule play a significant role as ligands in stereosel ective synthesis and in the formation of supramolecular aggregates. Accordingly, we selected 2-, 3- and 4-pyridyl as aryl groups.

An attempt to prepare bis(2-pyridylethynyl) derivative by the Negishi reaction gave desired product 7 only in 31\% yield (Scheme 3 ). This product was obtained under the Sonogashira reaction conditions in a significantly better yield (80\%) within $2 \mathrm{~h}$. 


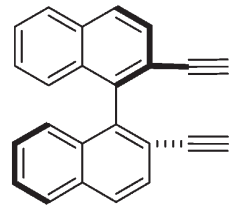

$(R S)-$ and $(R)-16$
Method A: Negishi

1) $\mathrm{BuLi}, \mathrm{THF}, 2) \mathrm{ZnCl}_{2}$,

3) $2-\mathrm{BrC}_{5} \mathrm{H}_{4} \mathrm{~N}, 5 \%\left[\mathrm{Pd}\left(\mathrm{PPh}_{3}\right)_{4}\right]$, , 12h

Method B: Sonogashira

2- $\mathrm{BrC}_{5} \mathrm{H}_{4} \mathrm{~N}, 5 \% \mathrm{Cul}, 5 \%\left[\mathrm{Pd}\left(\mathrm{PPh}_{3}\right)_{4}\right]$,

$\mathrm{Et}_{3} \mathrm{~N}, \mathrm{PhMe}, 80^{\circ} \mathrm{C}, 2 \mathrm{~h}$
$31 \%$

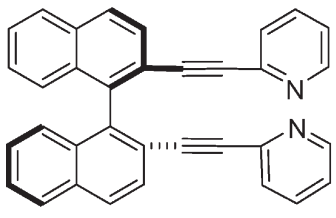

$(R S)$ - and $(R)-7$

\section{SCHEME 3}

3-Pyridyl and 4-pyridyl derivatives 8 and $\mathbf{9}$ were prepared in analogous manner in 85 and $47 \%$ yield, respectively (Scheme 4). It should be noted that 4-pyridyl derivative 9 was not stable and decomposed even at low temperature and under argon atmosphere within few days.

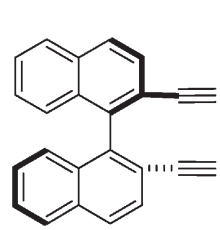

$(R S)$ - and $(R)-16$

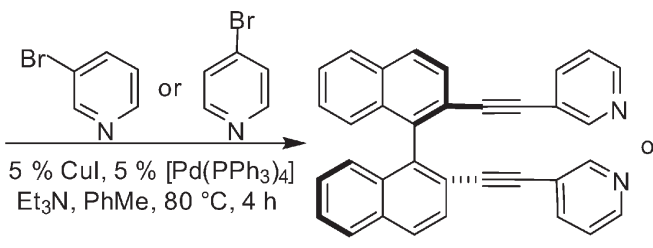

$(R S)$ - and $(R)-8,85 \%$

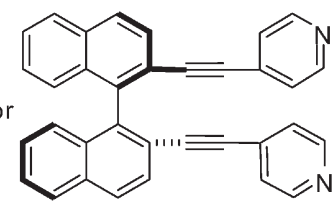

$(R S)$ - and $(R)-9,47 \%$

SCHEME 4

Structure of new 2,2'-bis(pyridylethynyl)-1,1'-binaphthalenes 7-9 was confirmed by UV-VIS, IR, ${ }^{1} \mathrm{H}$ NMR, ${ }^{13} \mathrm{C}$ NMR spectra, and elemental analysis.

Study on Coordination of 2,2'-Bis(pyridylethynyl)-1,1'-binaphthalene Derivatives

Molecular modeling (AM 1 method within HyperChem) of compounds 7, 8 and $\mathbf{9}$ in the presence of zinc chloride showed that spatial orientation of nitrogen donor atoms allows formation of bidentate chelate complex only from ligand 7. In the case of ligands $\mathbf{8}$ and $\mathbf{9}$, nitrogen lone electron pairs are oriented divergently, so these ligands should prefer formation of coordination dimers or oligomers (at ligand-to-metal ratio 1:1) or formation of bridged complexes M-L-M (at ligand-to-metal ratio 1:2).

Molecular structure of the chelate of (RS)-7 with palladium chloride is reported in following chapter. The chelate clearly demonstrated the ability of ligand $\mathbf{7}$ to form intramolecular bidentate complex. Determination of the 
exact structures of chelates of $\mathbf{8}$ and $\mathbf{9}$ would be al so possible by X-ray structure analysis. Until now, we have failed to obtain crystals suitable for this purpose.

Coordination of bis(2-pyridylethynyl) 7, bis(3-pyridylethynyl) 8 and bis(4-pyridylethynyl) 9 derivatives with $\mathrm{Zn}^{2+}$ ions was studied by ${ }^{1} \mathrm{H}$ NMR titration. Formation of white precipitate was observed in the case of $\mathbf{7}$. We failed to crystallize or dissolve it in any common solvent. In DMSO, decomposition of the complex and formation of starting $\mathbf{7}$ were observed.

Coordination of the compound (RS)-8 to the zinc cation affected proton ${ }^{1} \mathrm{H}$ NMR chemical shifts of $\mathbf{8}$, which reflects different architecture of the complexes formed, keeping $\mathrm{C}_{2}$-symmetry of the ligand. ${ }^{1} \mathrm{H}$ NMR spectra (Fig. 2) obtained by successive addition of zinc chloride gave time-averaged signals, partially broadened, until whole numbers ratio of the components was reached as a result of metal-ligand exchange. Some signals (e.g. at 8.34 ppm of uncomplexed ligand) exhibited a complexation-induced shift to the lower field within the ligand-to-metal ratio ranging from 1:0 to $1: 1$ and then remained unchanged while increasing the zinc cation amount (up to $\Delta \delta 0.28 \mathrm{ppm}$ ). Some other signals (e.g. at $7.88 \mathrm{ppm}$ ) were more affected by addition of zinc cation ( $>1$ equiv.).

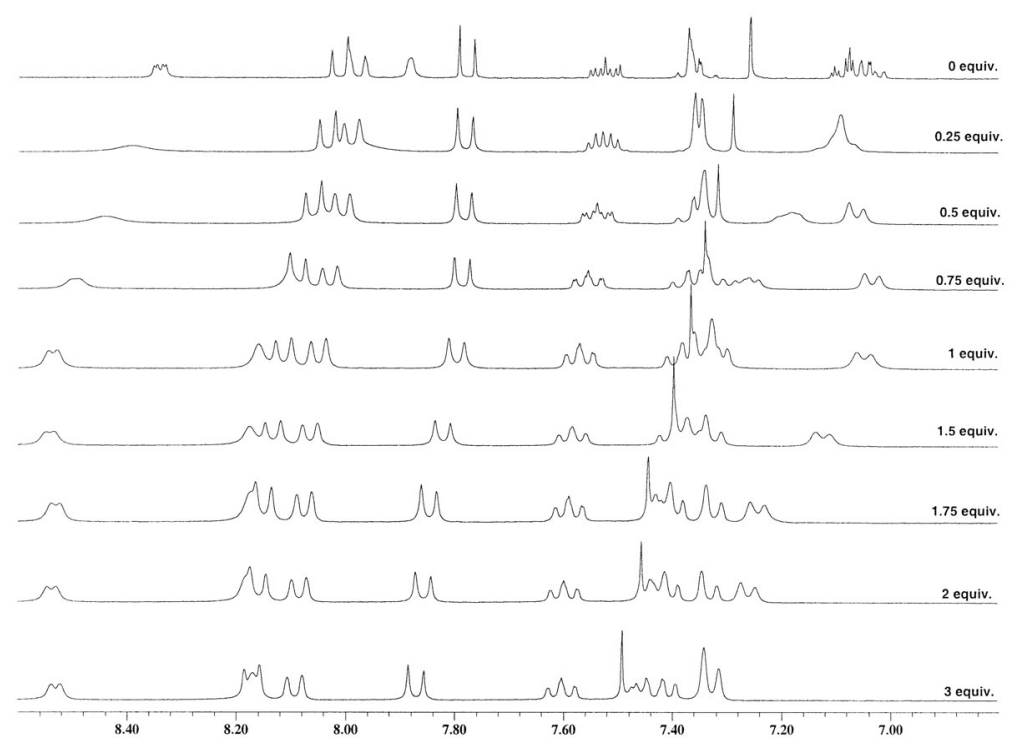

FIG. 2

${ }^{1} \mathrm{H}$ NMR spectra of (RS)-8 (c $0.01 \mathrm{~mol} / \mathrm{l}$ ) after addition of corresponding amounts of $\mathrm{ZnCl}_{2}$, in $\mathrm{CDCl}_{3}-\mathrm{CD}_{3} \mathrm{CN}$ mixture (1:1) 
The same spectra were observed during the successive addition of zinc chloride to enantiopure (R)-8, reflecting the same architecture of the complexes regardless of the enaniomeric purity of ligand $\mathbf{8}$.

Analogous changes were observed also in ${ }^{1} \mathrm{H}$ NMR spectra during addition of zinc chloride to ligand (RS)-9 (Fig. 3). $\mathrm{C}_{2}$-Symmetry of the ligand was kept. However, significant changes were detected only until the addition of one equivalent of zinc chloride, which points out increased stability of the 1:1 complex. Complexation with (R)-9 showed an analogous profile as in the case of (RS) $-\mathbf{9} / \mathrm{ZnCl}_{2}$.

Coordination of 2,2'-bis(2-pyridylethynyl)- (7) and 2,2'-bis(3-pyridylethynyl)1,1'-binaphthalenes (8) to silver ions was studied by CD titration (Fig. 4). In $C D$ spectra of ligand (R)-7, decrease in the intensity of the bisignate signal of the CD couplet was observed upon successive addition of silver ions. The intensity of the signal originating from the ${ }^{1} B_{b}$ electronic transition of the binaphthalene moiety ${ }^{19}$, here at 307 and $335 \mathrm{~nm}$, is known to decrease upon increasing the dihedral angle between two naphthalene units closer to $90^{\circ} 20$. Formation of an intramolecular bidentate complex (analogous to that with palladium ion characterized by $\mathrm{X}$-ray structure analysis; see the

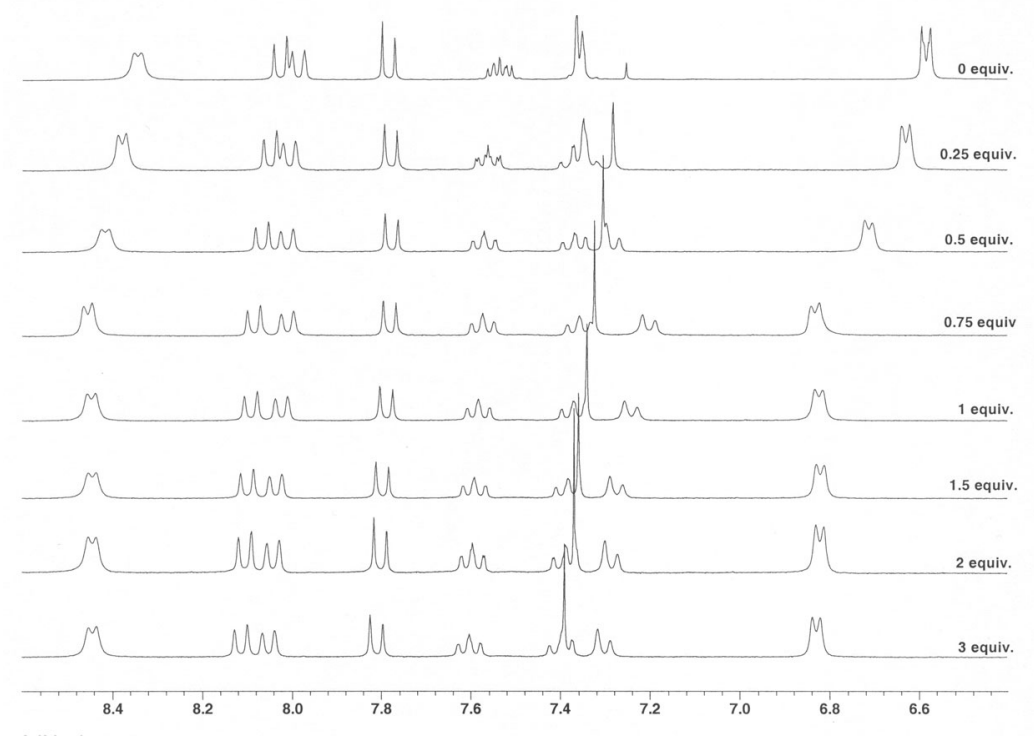

FIG. 3

${ }^{1} \mathrm{H}$ NMR spectra of (RS)-9 (c $0.012 \mathrm{~mol} / \mathrm{l}$ ) after addition of corresponding amounts of $\mathrm{ZnCl}_{2}$, in $\mathrm{CDCl}_{3}-\mathrm{CD}_{3} \mathrm{CN}$ mixture (1:1) 
next chapter) seems to be responsible for the increase in the binaphthalene dihedral angle. In contrast, in the complexation of ligand (R)-8, where formation of an intermolecular complex is expected (dimer or oligomer), no remarkable change in CD spectra was observed, since formation of intermolecular complex does not require change in the dihedral angle of the binaphthalene moiety.
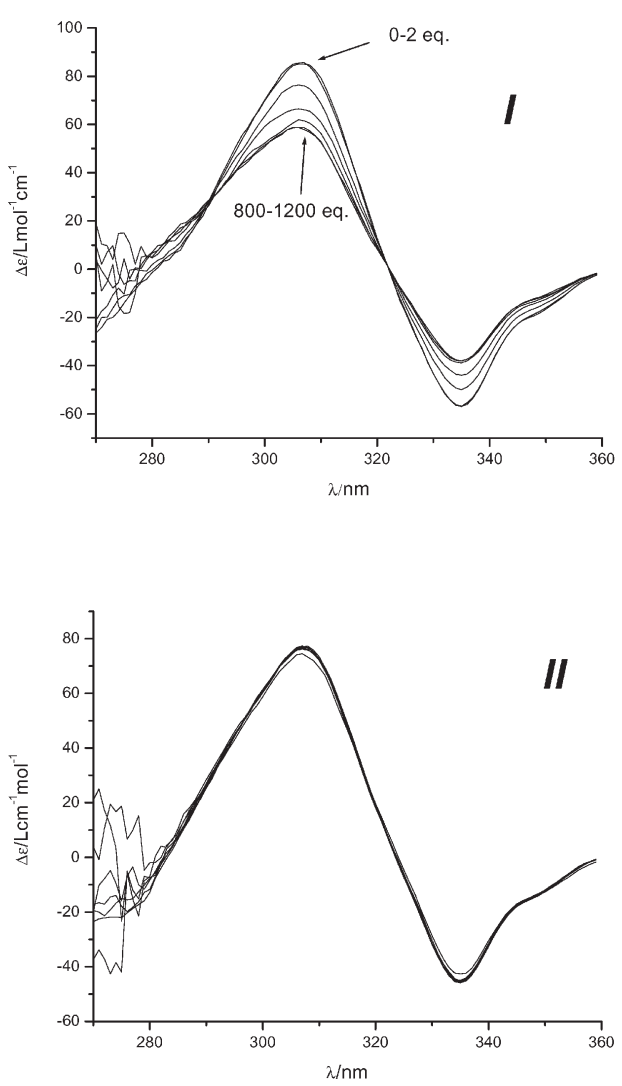

FIG. 4

CD spectra of: (R)-7 (c $1 \times 10^{-5} \mathrm{~mol} / \mathrm{l}$ ) after addition of $0,1,2,100,200,400,600,800,1000$ and 1200 equiv. of AgOTf (a); (R)-8 (c $1 \times 10^{-5} \mathrm{~mol} / \mathrm{l}$ ) after addition of $0,1,2,50,250,500,750$ and 1000 equiv. of AgOTf (b); in THF 


\section{X-ray Structure Analysis}

Diffusion of a solution of $\left[\mathrm{Pd}\left(\mathrm{CH}_{3} \mathrm{CN}\right)_{2} \mathrm{Cl}_{2}\right]$ in acetonitrile to a solution (RS)-7 in $\mathrm{CH}_{2} \mathrm{Cl}_{2}$ yielded $77 \%$ of orange crystals of complex $\left[\mathrm{PdCl}_{2}(\mathrm{RS})-7\right] \cdot \mathrm{CH}_{3} \mathrm{CN}$ (17). The X-ray diffraction study showed that the crystal was composed of both enantiomers, each of them being coordinated to $\mathrm{PdCl}_{2}$ and cocrystallizing with one molecule of acetonitrile (Fig. 5). Nitrogen atoms occupy trans position to the chlorine atoms bonded to palladium and gave a slightly distorted square-planar coordination geometry with typical averaged distances ${ }^{21} \mathrm{Pd}-\mathrm{Cl}$ (2.31 and $2.35 \AA$ ) and $\mathrm{Pd}-\mathrm{N}$ (pyridine) (2.04 $\AA$ ), respectively. The bond angles of $\mathrm{N}-\mathrm{Pd}-\mathrm{N}, \mathrm{Cl}-\mathrm{Pd}-\mathrm{Cl}$, and $\mathrm{N}-\mathrm{Pd}-\mathrm{Cl}$ are 176.5, 173.3, and 88.2, 89.3 ${ }^{\circ}$, respectively. Torsion angles between naphthalene moieties were $-73.1^{\circ}$ for one enantiomer of 7 and $-74.5^{\circ}$ for the other one; torsion angles between pyridine planes were -32.9 and $-35.3^{\circ}$. One of the $\mathrm{C}-\mathrm{C} \equiv \mathrm{C}-\mathrm{C}$ chains was slightly deviated from linearity, with bond angle C(23)-C(24)-C(25) being $167.7^{\circ}$.

The supramolecular structure of complex 17 (Fig. 6) is composed of homochiral chains formed by complex molecules in a parallel orientation. The structure is directed by weak $\mathrm{Cl} \cdots \mathrm{H}$ intermolecular short contacts of $2.89 \AA$ (between $\mathrm{Cl}(2)-\mathrm{H}(19)$ of two complex molecules from a chain) and

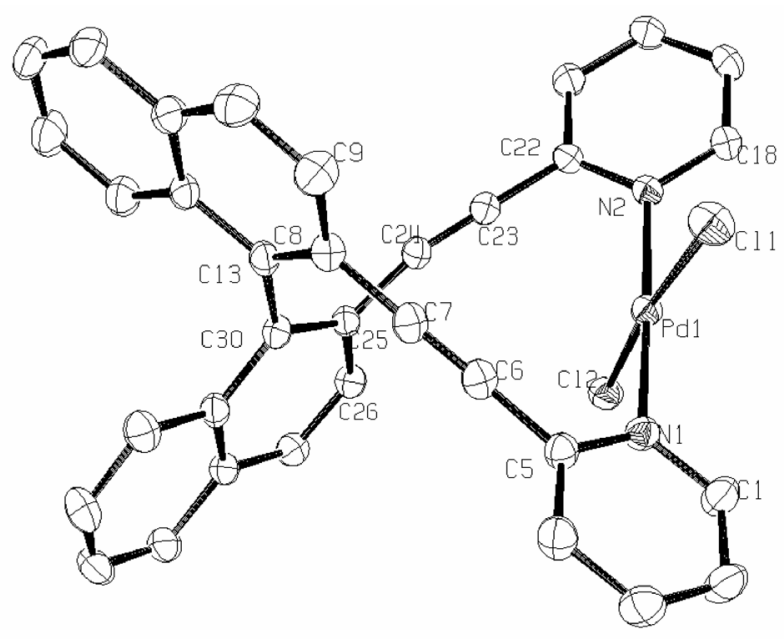

FIG. 5

ORTEP diagram of structure 17. Thermal ellipsoids are drawn at the $50 \%$ probability level. Hydrogen atoms and solvent molecule were omitted for clarity 
2.80 $\AA$ (between $\mathrm{Cl}(2)-\mathrm{H}(20)$ of molecules of neighboring chain), below the sum of van der Waals radii $(3.45 \AA$ ). Weak $\mathrm{Cl} \cdots \mathrm{H}$ intermolecular short contacts $(2.78 \AA$ ) between $\mathrm{Cl}(1)-\mathrm{H}(26)$ of the molecules of a chain are observed in the molecular structure of $\mathbf{1 7}$ as well. No $\pi-\pi$ stacking interaction of naphthalene units between complex molecules was observed since the shortest distance between centroids of naphthalene moieties was $4.39 \AA$.
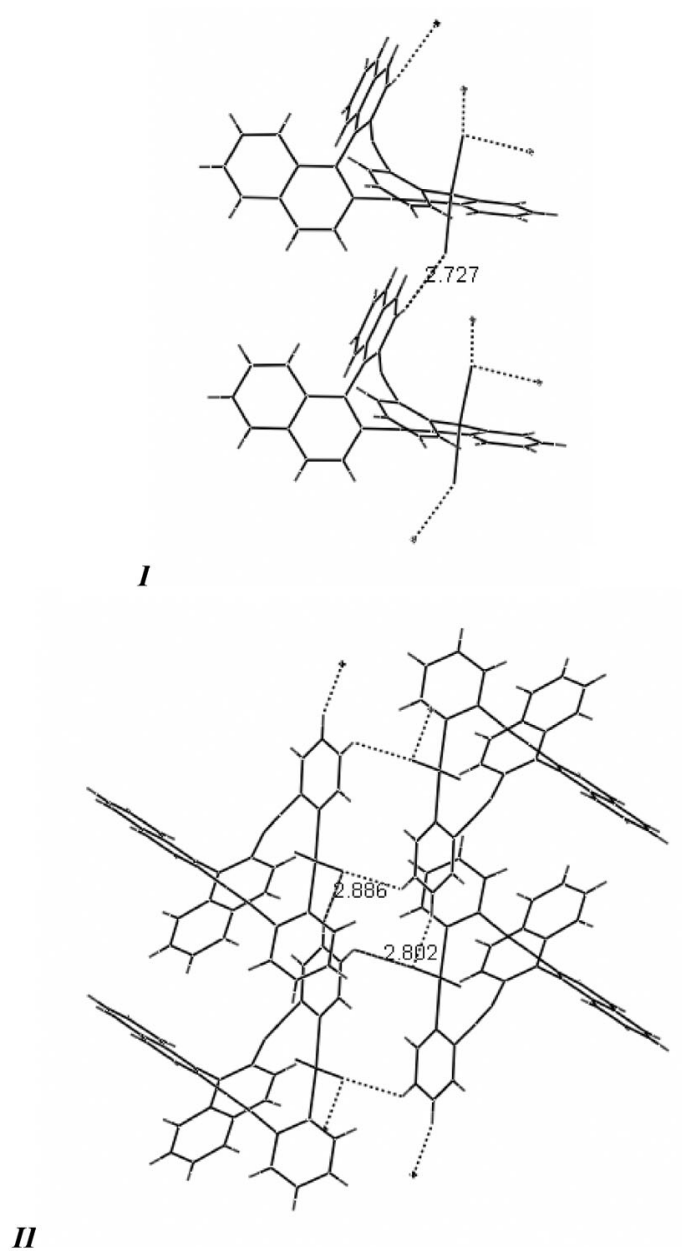

FIG. 6

Schematic representation of supramolecular structure of 17. Intermolecular short contacts are shown by dotted lines. Solvent molecules are omitted for clarity. I Chain of the homochiral complexes; II two adjacent chains 


\section{CONCLUSION}

We have developed an expedient methodology for the synthesis of enantiopure 2,2'-dialkynyl-1,1'-binaphthalene derivatives $\mathbf{1 3}$ and $\mathbf{1 5}$. Compound 16 bearing ethynyl groups served as precursor for synthesis of bispyridine derivatives 7-9 by the Sonogashira coupling in moderate to high yield. Coordination of metal ions to the prepared bispyridines was observed by NMR and CD spectroscopy and the coordination of palladium cation was determined by X-ray structure analysis. Applications of the prepared bispyridines 7-9 as chiral ligands, supramolecular synthons or functional materials, are the subject of intensive study in our laboratory.

\section{EXPERIMENTAL}

Flash column chromatography was performed on Merck Silica Gel $(60 \mathrm{H})$. Merck Silica Gel F254 plates were used for thin layer chromatography and visualization was effected with UV light $(254 \mathrm{~nm})$. Melting points were measured on a Kofler block; the values are uncorrected. Specific optical rotations were measured on a Perkin-Elmer 241 polarimeter and are given in deg $\mathrm{cm}^{2} \mathrm{~g}^{-1} \mathrm{dm}^{-1}$. IR data (in $\mathrm{cm}^{-1}$ ) were recorded on a Specord M 80 spectrophotometer. UV-VIS spectra were measured on a Hewlett-Packard diode array 8245 spectrophotometer. CD spectra were measured on a Jasco $J 710$ instrument. ${ }^{1} \mathrm{H}$ NMR and ${ }^{13} \mathrm{C}$ NMR spectra were recorded on a Varian Gemini 300 instrument at $298 \mathrm{~K}$. Chemical shifts are reported in ppm ( $\delta$-scale) relative to internal standard TMS $(0.00 \mathrm{ppm})$, the solvent was used as a reference. The operation frequency was $300 \mathrm{MHz}$ for ${ }^{1} \mathrm{H}$ and $75.5 \mathrm{MHz}$ for ${ }^{13} \mathrm{C}$ NMR. Coupling constants (J) are given in Hz. GC-MS spectra (70 eV, $150 \mu \mathrm{A}$, El) were recorded on a Voyager GC/MS Finnigan instrument. Elemental analyses were determined with an Erba Science 1106 instrument. HPLC analysis was done on a Chiralcel Daicel OD-H column using an Agilent 1100 diode array detector (UV-VIS).

Dichloromethane, pyridine and triethylamine were dried with calcium chloride under argon atmosphere. THF, toluene and diethyl ether were dried with sodium/benzophenone. BuLi was used as $1.6 \mathrm{~m}$ solution in hexanes (Aldrich). All solvents for coupling reactions were degassed with a thaw-freeze pump in 3 cycles. The reactions were performed under argon atmosphere using Schlenk technique. $\left[\mathrm{Pd}\left(\mathrm{PPh}_{3}\right)_{4}\right]\left(\right.$ ref. $\left.^{22}\right)$, ditriflate (RS)-15 $\left(\right.$ ref. $\left.^{23}\right)$ were prepared according to literature procedures. All other chemicals were of analytical grade and were used without further purification.

\section{2,2'-Diiodo-1,1'-binaphthalene (10)}

Method A: (R)-1, $1^{\prime}$-Binaphthalene-2,2'-diamine $2 \mathrm{HCl}^{24}(5.00 \mathrm{~g}, 14 \mathrm{mmol},>98 \%$ ee by polarimetry) was dissolved in a $\mathrm{H}_{2} \mathrm{O}-\mathrm{CH}_{3} \mathrm{COOH}-\mathrm{H}_{2} \mathrm{SO}_{4}$ mixture $(195 \mathrm{ml}, 2: 10: 1, \mathrm{v} / \mathrm{v})$ at room temperature. The solution was cooled to $-5{ }^{\circ} \mathrm{C}$ and $\mathrm{NaNO}_{2}(4.00 \mathrm{~g}, 58 \mathrm{mmol})$ was added in three portions. The mixture was stirred at $0{ }^{\circ} \mathrm{C}$ for $2 \mathrm{~h}$ and then carefully added to a mixture of KI (17 g, $0.104 \mathrm{~mol})$ with ice $(200 \mathrm{ml}$ ) (intensive foaming). The reaction mixture was stirred at room temperature for $12 \mathrm{~h}$ and then extracted with chloroform. Combined organic extracts were washed with aqueous $\mathrm{Na}_{2} \mathrm{SO}_{3}$, dried over anhydrous $\mathrm{Na}_{2} \mathrm{SO}_{4}$, and 
solvent was evaporated. Purification through a short silica gel column (hexanes-chloroform, 10:1) gave compound (R)-10 as a white crystalline solid (3.57 g, 50\%, $99.1 \pm 0.2 \%$ ee by HPLC).

Method B: Procedure according to literature ${ }^{25}$, but starting from (R)-1,1'-binaphthalene$2,2^{\prime}$-diamine ( $>98 \%$ ee by polarimetry) afforded (R)-10 $(62 \%, 99.1 \pm 0.2 \%$ ee by HPLC).

(R)-2,2'-Diiodo-1,1'-binaphthalene (10). M.p. 227-229 ${ }^{\circ} \mathrm{C}$ (hexanes), $[\alpha]_{D}^{23}+16.7$ (c 1.75, pyridine), $>98 \%$ ee (lit. ${ }^{24}$ m.p. $225-227{ }^{\circ} \mathrm{C},[\alpha]_{D}^{23}+16.4$ (c 1.725 , pyridine), $>98 \%$ ee). Spectral data were in agreement with literature values ${ }^{25}$. (RS)-10: M.p. 205-207 ${ }^{\circ} \mathrm{C}$. HPLC: Chiralcel Daicel OD-H column, heptane-DME (99:1), temperature $16{ }^{\circ} \mathrm{C}$, flow rate $1 \mathrm{ml} / \mathrm{min}$, pressure 31 bar, $\lambda=280 \mathrm{~nm}$; $k=6.52(\mathrm{~S})-10,7.35(\mathrm{R})-10, \alpha=1.13, \mathrm{R}_{\mathrm{S}}=1.42$.

\section{Alkynylation of 2,2'-Disubstituted 1,1'-Binaphthalenes}

Preparation of (Phenylethynyl)magnesium Bromide

To $\mathrm{Mg}$ turnings (144 mg, $6 \mathrm{mmol})$ in THF $(20 \mathrm{ml}) 2$ drops of 1,2-dibromomethane were added. Then isopropyl bromide $(0.28 \mathrm{ml}, 3 \mathrm{mmol})$ was added and the mixture was heated to reflux for $2 \mathrm{~h}$. The reaction mixture was cooled to $-30{ }^{\circ} \mathrm{C}$ and phenylacetylene $(0.34 \mathrm{ml}$, $3 \mathrm{mmol}$ ) was injected via syringe. The reaction mixture was then refluxed for $2 \mathrm{~h}$. The filtered mixture was used in subsequent reactions.

\section{Preparation of Alkynylzinc Chloride}

To a solution of terminal acetylene $(3 \mathrm{mmol})$ in THF $(10 \mathrm{ml})$ was added dropwise butyllithium $(2.25 \mathrm{ml}, 3.6 \mathrm{mmol})$ solution in hexane at $0{ }^{\circ} \mathrm{C}$. The obtained solution was stirred at this temperature for $30 \mathrm{~min}$. Then a $1.5 \mathrm{~m}$ solution of $\mathrm{ZnCl}_{2}$ in THF $(3.6 \mathrm{mmol}$ ) was added and stirred at $0{ }^{\circ} \mathrm{C}$ for $30 \mathrm{~min}$.

\section{3-(Trimethylsilyl)-4-[(trimethylsilyl)ethynyl]dibenzo[c,g]phenanthrene (12)}

A Schlenk flask containing a stirring bar, capped with a rubber septum, was flame-dried under vacuum and then filled with argon and cooled to room temperature. The flask was charged with 10 (200 mg, $0.4 \mathrm{mmol})$, [Pd( $\left.\left(\mathrm{PPh}_{3}\right)_{4}\right]$ (10 mg, $\left.0.02 \mathrm{mmol}, 2.5 \mathrm{~mole} \%\right)$, Cul (305 $\mathrm{mg}, 1.6 \mathrm{mmol})$, and again evacuated and filled with argon. Dry $\mathrm{Et}_{3} \mathrm{~N}(0.9 \mathrm{ml}, 6.4 \mathrm{mmol}$, absolute THF (10 ml) and (trimethylsilyl)acetylene $(1.6 \mathrm{mmol})$ was injected into the flask and the reaction mixture was heated to reflux for $12 \mathrm{~h}$ under argon atmosphere. After cooling, the reaction mixture was poured into $10 \%$ aqueous $\mathrm{HCl}$ and extracted three times with chloroform (10-ml portions). Combined organic fractions were washed twice with water and brine, and dried over anhydrous $\mathrm{Na}_{2} \mathrm{SO}_{4}$. After filtration and evaporation of the solvent, the residue was chromatographed on silica gel (hexanes-chloroform, 10:1). $146 \mathrm{mg}$ (82\%) of 12 as dark red oil was obtained. $\mathrm{R}_{\mathrm{F}} 0.62$ (hexanes-chloroform, 4:1). ${ }^{1} \mathrm{H} \mathrm{NMR}\left(300 \mathrm{M} \mathrm{Hz} \mathrm{CDCl}_{3}\right.$ ): $9.33 \mathrm{~d}, 1 \mathrm{H},{ }^{3} \mathrm{~J}=8.4(\mathrm{Ar}-\mathrm{H}) ; 8.46-8.23 \mathrm{~m}, 2 \mathrm{H}(\mathrm{Ar}-\mathrm{H}) ; 8.05 \mathrm{~d}, 1 \mathrm{H},{ }^{3} \mathrm{~J}=8.4(\mathrm{Ar}-\mathrm{H}) ; 7.90-7.83$ m, $2 \mathrm{H}(\mathrm{Ar}-\mathrm{H}) ; 7.80 \mathrm{~d}, 1 \mathrm{H},{ }^{3} \mathrm{~J}=8.2(\mathrm{Ar}-\mathrm{H}) ; 7.73 \mathrm{~d}, 1 \mathrm{H},{ }^{3} \mathrm{~J}=8.2(\mathrm{Ar}-\mathrm{H}) ; 7.80-7.38 \mathrm{~m}, 4 \mathrm{H}$ $(\mathrm{Ar}-\mathrm{H}) ; 0.61 \mathrm{~s}, 9 \mathrm{H}\left(\mathrm{SiCH}_{3}\right) ; 0.42 \mathrm{~s}, 9 \mathrm{H}\left(\mathrm{SiCH}_{3}\right) .{ }^{13} \mathrm{CNMR}\left(75 \mathrm{MHz}, \mathrm{CDCl}_{3}\right): 139.4,138.3$, $137.0,135.3,135.0,128.8,128.6,128.5,128.3,128.0,127.9,127.8,127.7,126.5,126.1$, $125.9,125.3,125.1,123.2,122.8,116.9,108.9,1.4,0.1$. For $\mathrm{C}_{30} \mathrm{H}_{30} \mathrm{Si}_{2}$ (446.7) calculated: $80.66 \% \mathrm{C}, 6.77 \% \mathrm{H}$; found: $80.43 \% \mathrm{C}, 6.85 \% \mathrm{H}$. 
(RS)-, (R)-2,2'-Bis(phenylethynyl)-1,1'-binaphthalene (13) via Stephen-Castro Reaction

A dried Schlenk flask containing a stirring bar, capped with a rubber septum, was flamedried under vacuum and then filled with argon and cooled to room temperature. The flask was charged with (R)-10 (100 mg, $0.2 \mathrm{mmol}, 99 \%$ ee) and copper(I) phenylacetylide (165 mg, $1 \mathrm{mmol})$, evacuated again and filled with argon. Dried pyridine $(5 \mathrm{ml})$ was successively injected into the flask and the reaction mixture was heated to reflux for $20 \mathrm{~h}$ under argon atmosphere. After cooling, the reaction mixture was poured into $15 \%$ aqueous $\mathrm{HCl}$ and extracted three times with chloroform (10-ml portions). Combined organic fractions were washed twice with water and brine, and dried over anhydrous $\mathrm{Na}_{2} \mathrm{SO}_{4}$. After filtration and evaporation of the solvent, the residue was chromatographed on silica gel (hexanes- chloroform, 10:1); enantiomeric enriched (R)-13 (28 mg, 31\%, 99\% ee, HPLC) as a white solid was obtained.

2,2'-Bis(phenylethynyl)- (13) and 2,2'-Bis[(trimethylsilyl)ethynyl]-1,1'-binaphthalene (15) via Negishi Reaction

Method A (under classical heating): A dried Schlenk flask containing a stirring bar, capped with a rubber septum, was flame-dried under vacuum and then filled with argon and cooled to room temperature. The flask was charged with $(\mathrm{R})-\mathbf{1 0}(100 \mathrm{mg}, 0.2 \mathrm{mmol})$ and $\left[\mathrm{Pd}\left(\mathrm{PPh}_{3}\right)_{4}\right]$ (11.5 mg, $0.01 \mathrm{mmol}$ ) (or another catalytic system), evacuated again and filled with argon. Dry THF $(1 \mathrm{ml})$ was injected into the flask and a solution of alkynylzinc chloride was injected via cannula to the reaction mixture. The reaction mixture was heated to reflux (ca. $65^{\circ} \mathrm{C}$ ) for the time given in Table I. After cooling to room temperature, the mixture was quenched with $10 \%$ aqueous $\mathrm{HCl}(15 \mathrm{ml})$ and extracted three times with chloroform. Combined organic layers were washed with water and brine, and dried over anhydrous $\mathrm{Na}_{2} \mathrm{SO}_{4}$. Solvent was evaporated and 2,2'-diethynyl-1,1'-binaphthalenes $\mathbf{1 3}$ and $\mathbf{1 5}$ were obtained from the residue by flash chromatography on silica gel (hexanes-chloroform, 9:1).

Method B (under microwave irradiation): To a solution of (R)-10 (100 mg, $0.2 \mathrm{mmol}$ ) and $\left[\mathrm{Pd}\left(\mathrm{PPh}_{3}\right)_{4}\right](11.5 \mathrm{mg}, 0.01 \mathrm{mmol}$ ) (or another catalytic system) in dry THF $(1 \mathrm{ml})$, a solution of alkynylzinc chloride was added. The MW reactor vessel was capped and irradiated in a Biotage Initiator microwave oven at $120^{\circ} \mathrm{C}$ for the total irradiation time indicated in Table I. After cooling to room temperature, the mixture was quenched with $10 \%$ aqueous $\mathrm{HCl}$ $(15 \mathrm{ml})$ and extracted three times with chloroform. Combined organic layers were washed with water and brine, and dried over anhydrous $\mathrm{Na}_{2} \mathrm{SO}_{4}$. Solvent was evaporated and 2,2'-diethynyl-1,1'-binaphthalenes $\mathbf{1 3}$ and $\mathbf{1 5}$ were obtained from the residue by flash chromatography on silica gel (hexanes-chloroform, 9:1).

(R)-2,2'-Bis(phenylethynyl)-1,1'-binaphthalene (13). White solid, m.p. 200-203 ${ }^{\circ} \mathrm{C}, 99 \%$ ee (determined by HPLC), $[\alpha]_{D}^{22}+6.92$ (c 1 , chloroform) (lit. ${ }^{15}[\alpha]_{D}^{30.5}+6.91$ (c 1.01, chloroform)), $\mathrm{R}_{\mathrm{F}} 0.27$ (chloroform-hexanes, 1:4). Spectral data were in agreement with literature values ${ }^{14}$. (RS)-13: m.p. 224-228 ${ }^{\circ} \mathrm{C}$ (chloroform-hexanes) (lit. ${ }^{14}$ m.p. 263-264 ${ }^{\circ} \mathrm{C}\left(\mathrm{EtOH}-\mathrm{CH}_{2} \mathrm{Cl}_{2}\right.$ )). HPLC: Chiralcel Daicel OD-H column, hexane-DME (99:1), temperature $21{ }^{\circ} \mathrm{C}$, flow rate $1 \mathrm{ml} / \mathrm{min}$, pressure $47 \mathrm{bar}, \lambda=280 \mathrm{~nm} ; \mathrm{k}=2.32(\mathrm{~S})-13,2.79(\mathrm{R})-13 ; \alpha=1.20 ; \mathrm{R}_{\mathrm{S}}=1.30$.

(RS)-, (R)-2,2'-Bis[(trimethylsilyl)ethynyl]-1,1'-binaphthalene (15). Yellowish oil, $R_{F} 0.52$ (chloroformhexanes, 1:4). ${ }^{1} \mathrm{H}$ NMR (300 $\left.\mathrm{MHz} \mathrm{CDCl}_{3}\right): 7.88 \mathrm{~d}, 2 \mathrm{H},{ }^{3} \mathrm{~J}=8.4(\mathrm{Ar}-\mathrm{H}) ; 7.86 \mathrm{~d}, 2 \mathrm{H},{ }^{3} \mathrm{~J}=8.1$ $(\mathrm{Ar}-\mathrm{H}) ; 7.63 \mathrm{~d}, 2 \mathrm{H},{ }^{3} \mathrm{~J}=8.7(\mathrm{Ar}-\mathrm{H}) ; 7.46 \mathrm{ddd}, 2 \mathrm{H}$, J = 3.5, 8.1, 8.2 (Ar-H); $7.29 \mathrm{~m}, 4 \mathrm{H}(\mathrm{Ar}-\mathrm{H})$; $-0.28 \mathrm{~s}, 18 \mathrm{H}\left(\mathrm{Si}-\mathrm{CH}_{3}\right) .{ }^{13} \mathrm{C} \mathrm{NMR}\left(75 \mathrm{MHz} \mathrm{CDCl}_{3}\right): 141.8,133.7,133.2,128.6,128.5,128.3$, 127.3, 127.1, 127.0, 121.9, 105.5, 99.1, 0.03. 


\section{2,2'-Diethynyl-1,1'-binaphthalene (16)}

Finely powdered and dried $\mathrm{K}_{2} \mathrm{CO}_{3}(500 \mathrm{mg}, 3.6 \mathrm{mmol})$ was added to a solution of (R)-15 (268 $\mathrm{mg}, 0.6 \mathrm{mmol}$ ) in MeOH-THF (10 ml, 1:1). The reaction mixture was stirred at room temperature for $4 \mathrm{~h}$, and chloroform $(35 \mathrm{ml})$ and water $(15 \mathrm{ml})$ were added. The organic layer was separated, washed with water and brine, and dried over anhydrous $\mathrm{Na}_{2} \mathrm{SO}_{4}$. After filtration, solvent was evaporated and the residue was purified by flash chromatography on silica gel (hexanes-chloroform, 9:1). Compound 16 (165 mg, 91\%) was obtained as a white solid.

(R)-2,2'-Diethynyl-1,1'-binaphthalene (16). M.p. 190-194 ${ }^{\circ} \mathrm{C}$ (chloroform-hexanes), $[\alpha]_{D}^{23}$ +27.7 (c 0.62 , chloroform), $>98 \%$ ee (determined by HPLC), $R_{F} 0.37$ (chloroform-hexanes, 1:4). Spectral data were in agreement with literature values ${ }^{15}$. (RS)-16: m.p. 199-205 ${ }^{\circ} \mathrm{C}$. HPLC: Chiralcel Daicel OD-H column, hexane-DME (99:1), temperature $21{ }^{\circ} \mathrm{C}$, flow rate $1 \mathrm{ml} / \mathrm{min}$, pressure 47 bar, $\lambda=280 \mathrm{~nm} ; \mathrm{k}=2.74(\mathrm{~S})-16,3.05(\mathrm{R})-16 ; \alpha=1.11 ; \mathrm{R}_{\mathrm{S}}=0.89$.

\section{Synthesis of Bispyridines 7-9}

\section{2,2'-Bis(2-pyridylethynyl)-1,1'-binaphthalene (7)}

Method A (Negishi reaction): A dried Schlenk flask containing a stirring bar, capped with a rubber septum, was flame-dried under vacuum, filled with argon and cooled to room temperature. The flask was charged with 15 (100 $\mathrm{mg}, 0.33 \mathrm{mmol})$, evacuated again and filled with argon. THF ( $1 \mathrm{ml})$ was successively injected into the flask and ice cooled. To this solution BuLi $\left(0.53 \mathrm{ml}, 0.79 \mathrm{mmol}, 1.6 \mathrm{~m}\right.$ solution in hexanes) was added dropwise at $0{ }^{\circ} \mathrm{C}$. After addition, the solution was stirred at $0{ }^{\circ} \mathrm{C}$ for $1 \mathrm{~h}$. Then solution of $\mathrm{ZnCl}_{2}(162 \mathrm{mg}$, $1.18 \mathrm{mmol})$ in THF $(1 \mathrm{ml})$ was added dropwise at $0{ }^{\circ} \mathrm{C}$ to it and the reaction mixture was stirred at $0{ }^{\circ} \mathrm{C}$ for $1 \mathrm{~h}$. The resulting solution was added to a solution of 2-bromopyridine $(0.19 \mathrm{ml}, 1.98 \mathrm{mmol})$ and $\left[\mathrm{Pd}\left(\mathrm{PPh}_{3}\right)_{4}\right](20 \mathrm{mg}, 0.0165 \mathrm{mmol})$ in THF $(3 \mathrm{ml})$ at room temperature and the mixture was heated to reflux for $12 \mathrm{~h}$. After cooling, the mixture was quenched with water $(2 \mathrm{ml})$ and extracted three times with chloroform $(10 \mathrm{ml})$. Combined organic layers were dried over anhydrous $\mathrm{Na}_{2} \mathrm{SO}_{4}$, filtered and solvent was evaporated. The residue was chromatographed on silica gel (hexanes-ethyl acetate, 1:1). Compound 7 (46 mg, $31 \%)$ as an off-white solid was obtained.

Method B (Sonogashira reaction): A dried Schlenk flask containing a stirring bar, capped with a rubber septum, was flame-dried under vacuum, filled with argon and cooled to room temperature. The flask was charged with 15 (60 $\mathrm{mg}, 0.2 \mathrm{mmol}), 2$-bromopyridine (78 mg, $0.5 \mathrm{mmol})$, Cul (2 mg, $0.01 \mathrm{mmol})$ and $\left[\mathrm{Pd}\left(\mathrm{PPh}_{3}\right)_{4}\right](11.5 \mathrm{mg}, 0.01 \mathrm{mmol})$, evacuated again and filled with argon. Toluene $(2.5 \mathrm{ml})$ and $\mathrm{Et}_{3} \mathrm{~N}(1 \mathrm{ml})$ were successively injected into the flask. The dark brown reaction mixture was heated to $80{ }^{\circ} \mathrm{C}$ for $2 \mathrm{~h}$. After cooling, water was added $\left(3 \mathrm{ml}\right.$ ), the mixture was poured into $10 \%$ aqueous $\mathrm{NH}_{4} \mathrm{Cl}$ and extracted three times with ethyl acetate (10-ml portions). Combined organic fractions were dried over anhydrous $\mathrm{Na}_{2} \mathrm{SO}_{4}$. After filtration and evaporation the solvent, the residue was chromatographed on silica gel (ethyl acetate-hexanes, gradient from 1:2 to 1:1). (RS)- or (R)-7 (72 mg, 80\%) as an off-white solid was obtained.

(R)-2,2'-Bis(2-pyridylethynyl)-1,1'-binaphthalene (7). M.p. 120-124 ${ }^{\circ} \mathrm{C},[\alpha]_{D}^{21}-75.8$ (c 1 , chloroform), $R_{F} 0.05$ (ethyl acetate-hexanes, 1:1). UV-VIS (MeOH (log $\varepsilon$ )): 226 (5.87), 268 (5.85), 316 (5.79). IR (chloroform): 2270 m, 2100 w, 1580 m, 1500 m, 1470 m, 1425 m, 920 m, 800 s, $695 \mathrm{~s}, 650$ w. ${ }^{1} \mathrm{H} \mathrm{NMR}\left(300 \mathrm{MHz} \mathrm{CDCl}_{3}\right): 8.42 \mathrm{~d}, 2 \mathrm{H},{ }^{3} \mathrm{~J}=4.4(\mathrm{Ar}-\mathrm{H}) ; 8.01 \mathrm{~d}, 2 \mathrm{H},{ }^{3} \mathrm{~J}=8.5$ $(\mathrm{Ar}-\mathrm{H}) ; 7.95 \mathrm{~d}, 2 \mathrm{H},{ }^{3} \mathrm{~J}=8.2(\mathrm{Ar}-\mathrm{H}) ; 7.87 \mathrm{~d}, 2 \mathrm{H},{ }^{3} \mathrm{~J}=8.4(\mathrm{Ar}-\mathrm{H}) ; 7.47-7.53 \mathrm{~m}, 2 \mathrm{H}(\mathrm{Ar}-\mathrm{H})$; 
$7.32 \mathrm{ddd}, 2 \mathrm{H}, \mathrm{J}=1.6,7.5,8.2(\mathrm{Ar}-\mathrm{H}) ; 7.32 \mathrm{~d}, 4 \mathrm{H},{ }^{3} \mathrm{~J}=3.6(\mathrm{Ar}-\mathrm{H}) ; 7.03 \mathrm{ddd}, 2 \mathrm{H}, \mathrm{J}=1.0,4.9$, $7.5(\mathrm{Ar}-\mathrm{H}) ; 6.32 \mathrm{~d}, 2 \mathrm{H},{ }^{3} \mathrm{~J}=7.91(\mathrm{Ar}-\mathrm{H}) .{ }^{13} \mathrm{C} \mathrm{NMR}\left(75 \mathrm{MHz} \mathrm{CDCl}_{3}\right): 149.8,143.5,141.0$, 135.9, 133.4, 132.7, 128.5, 128.3, 128.2, 127.6, 127.2, 127.1, 126.9, 122.5, 121.1, 92.8, 89.3. GC-MS-FAB, m/z (\%): 455 (100) $\left[\mathrm{M}^{\bullet+}-1\right]$, $378(62), 226$ (26). For $\mathrm{C}_{34} \mathrm{H}_{20} \mathrm{~N}_{2}$ (456.5) calculated: $89.45 \% \mathrm{C}, 4.42 \% \mathrm{H}, 6.14 \% \mathrm{~N}$; found: $89.73 \% \mathrm{C}, 4.50 \% \mathrm{H}, 5.85 \% \mathrm{~N}$. (RS)-7: m.p. 241-244 ${ }^{\circ} \mathrm{C}$ (chloroform-hexanes).

\section{2,2'-Bis(3-pyridylethynyl)-1,1'-binaphthalene (8)}

A dried Schlenk flask containing a stirring bar, capped with a rubber septum, was flame-dried under vacuum, filled with argon and cooled to room temperature. The flask was charged with 15 (100 mg, $0.33 \mathrm{mmol}$ ), 3-bromopyridine (128 mg, $0.825 \mathrm{mmol}$ ), Cul (3.3 mg, $0.0165 \mathrm{mmol})$ and $\left[\mathrm{Pd}\left(\mathrm{PPh}_{3}\right)_{4}\right](18.1 \mathrm{mg}, 0.0165 \mathrm{mmol})$, evacuated again and filled with argon. Toluene $(4.5 \mathrm{ml})$ and $\mathrm{Et}_{3} \mathrm{~N}(1.7 \mathrm{ml})$ were successively injected into the flask. The dark brown reaction mixture was heated to $80^{\circ} \mathrm{C}$ for $2 \mathrm{~h}$. After cooling, water $(3 \mathrm{ml})$ was added, the mixture was poured into $10 \%$ aqueous $\mathrm{NH}_{4} \mathrm{Cl}$ and extracted three times with ethyl acetate (10-ml portions). Combined organic fractions were dried over $\mathrm{Na}_{2} \mathrm{SO}_{4}$. After filtration and evaporation the solvent, the residue was chromatographed on silica gel (hexanes-ethyl acetate, gradient from 2:1 to 1:1). (RS)- or (R)-8 (177 mg, 85\%) as an off-white solid was obtained.

(R)-2,2'-Bis(3-pyridylethynyl)-1,1'-binaphthalene (8). M.p. $191-193{ }^{\circ} \mathrm{C},[\alpha]_{D}^{21}-2.9$ (c 1, chloroform), $R_{F} 0.10$ (ethyl acetate-hexanes, 1:1). UV-VIS (MeOH (log $\varepsilon$ )): 226 (6.59), 268 (6.78), 316 (6.32). IR (chloroform): 2275 m, 2095 m, 1595 m, 1530 m, 1470 m, 1420 m, 920 m, 800 s, $695 \mathrm{~s}, 650$ w. ${ }^{1} \mathrm{H}$ NMR (300 MHz, CDCl 3 ): $8.33 \mathrm{~d}, 2 \mathrm{H}, \mathrm{J}=3.1(\mathrm{py}-\mathrm{H}) ; 8.01 \mathrm{~d}, 2 \mathrm{H},{ }^{3} \mathrm{~J}=8.7$ $(\mathrm{Ar}-\mathrm{H}) ; 7.98 \mathrm{~d}, 2 \mathrm{H}, \mathrm{J}=9.56(\mathrm{Ar}-\mathrm{H}) ; 7.88 \mathrm{~s}, 2 \mathrm{H}(\mathrm{py}-\mathrm{H}) ; 7.78 \mathrm{~d}, 2 \mathrm{H}, 3 \mathrm{~J}=8.7(\mathrm{Ar}-\mathrm{H}) ; 7.52 \mathrm{ddd}$, $2 \mathrm{H}, \mathrm{J}=2.5,5.5,10.4(\mathrm{Ar}-\mathrm{H}) ; 7.32-7.39 \mathrm{~m}, 4 \mathrm{H}(\mathrm{Ar}-\mathrm{H}) ; 7.01-7.11 \mathrm{~m}, 4 \mathrm{H}(\mathrm{Ar}-\mathrm{H}) .{ }^{13} \mathrm{C} \mathrm{NMR}$ $\left(75 \mathrm{MHz}_{1} \mathrm{CDCl}_{3}\right): 152.2,148.3,140.8,138.1,133.4,132.7,128.5,128.3,128.1,127.2,127.1$, 126.8, 123.0, 122.95, 121.2, 92.6, 90.3. GC-MS-FAB: 456 (100) [M ${ }^{*+}$ ], 377 (18), 226 (16). For $\mathrm{C}_{34} \mathrm{H}_{20} \mathrm{~N}_{2}$ (456.5) calculated: $89.45 \% \mathrm{C}, 4.42 \% \mathrm{H}, 6.14 \% \mathrm{~N}$; found: $89.64 \% \mathrm{C}, 4.56 \% \mathrm{H}$, $5.83 \%$ N. (RS)-8: m.p. 223-225 ${ }^{\circ} \mathrm{C}$ (chloroform-hexanes).

\section{2,2'-Bis(4-pyridylethynyl)-1,1'-binaphthalene (9)}

A dried Schlenk flask containing a stirring bar, capped with a rubber septum, was flamedried under vacuum, filled with argon and cooled to room temperature. The flask was charged with 15 (200 mg, $0.66 \mathrm{mmol}$ ), 4-bromopyridine (256 mg, $1.65 \mathrm{mmol})$, Cul (6.3 mg, $0.033 \mathrm{mmol})$ and $\left[\mathrm{Pd}\left(\mathrm{PPh}_{3}\right)_{4}\right](36 \mathrm{mg}, 0.033 \mathrm{mmol})$, evacuated again and filled with argon. Toluene $(6 \mathrm{ml})$ and $\mathrm{Et}_{3} \mathrm{~N}(2 \mathrm{ml})$ were successively injected into the flask. The dark brown reaction mixture was heated to $80{ }^{\circ} \mathrm{C}$ for $2 \mathrm{~h}$. After cooling, water $(3 \mathrm{ml})$ was added, the mixture was poured into $10 \%$ aqueous $\mathrm{NH}_{4} \mathrm{Cl}$ and extracted three times with ethyl acetate (10-ml portions). Combined organic fractions were dried over anhydrous $\mathrm{Na}_{2} \mathrm{SO}_{4}$. After filtration and evaporation of the solvent, the residue was chromatographed on silica gel (hexanes-ethyl acetate, 2:1). (RS)- or (R)-9 (141 mg, 47\%) as an off-white solid was obtained. The product decomposes within several hours even at $-30{ }^{\circ} \mathrm{C}$ under argon atmosphere.

(R)-2,2'-Bis(4-pyridylethynyl)-1,1'-binaphthalene (9). M.p. $240-244{ }^{\circ} \mathrm{C},[\alpha]_{D}^{21}-5.0$ (c 0.85 , chloroform), $R_{F} 0.06$ (ethyl acetate-hexanes, 1:1). UV-VIS (MeOH (log $\varepsilon$ )): 228 (5.60), 280 (5.64), 324 (5.48). IR (chloroform): $2260 \mathrm{~m}, 2100 \mathrm{~m}, 1580 \mathrm{~s}, 1500 \mathrm{~m}, 1470 \mathrm{~m}, 1410 \mathrm{~m}, 985 \mathrm{~m}, 910 \mathrm{~m}$, $805 \mathrm{~s}, 680 \mathrm{~s}, 650 \mathrm{~m} .{ }^{1} \mathrm{H}$ NMR $\left(300 \mathrm{MHz} \mathrm{CDCl}_{3}\right): 8.34 \mathrm{~d}, 4 \mathrm{H},{ }^{3} \mathrm{~J}=4.4(\mathrm{py}-\mathrm{H}) ; 8.03 \mathrm{~d}, 2 \mathrm{H},{ }^{3} \mathrm{~J}=$ $8.5(\mathrm{Ar}-\mathrm{H}) ; 8.00 \mathrm{~d}, 2 \mathrm{H},{ }^{3} \mathrm{~J}=8.2(\mathrm{Ar}-\mathrm{H}) ; 7.78 \mathrm{~d}, 2 \mathrm{H},{ }^{3} \mathrm{~J}=8.5(\operatorname{Ar}-\mathrm{H}) ; 7.51-7.58 \mathrm{~m}, 2 \mathrm{H}(\operatorname{Ar}-\mathrm{H})$; 
$7.36 \mathrm{~d}, 4 \mathrm{H},{ }^{3} \mathrm{~J}=3.5(\mathrm{Ar}-\mathrm{H}) ; 6.58 \mathrm{~d}, 4 \mathrm{H}, \mathrm{J}=4.5\left(\right.$ py-H). ${ }^{13} \mathrm{C} \mathrm{NMR}\left(75 \mathrm{MHz} \mathrm{CDCl}_{3}\right): 149.5$, $141.2,133.5,132.6,131.3,128.5,128.3,128.1,127.4,127.3,126.7,125.2,120.7,93.8,90.9$. GC-MS-FAB: 456 (100) [ $\left.\mathrm{M}^{\bullet+}\right], 377$ (30), 213 (13), 199 (13). For $\mathrm{C}_{34} \mathrm{H}_{20} \mathrm{~N}_{2}$ (456.5) calculated: $89.45 \%$ C, $4.42 \% \mathrm{H}, 6.14 \% \mathrm{~N}$; found: $89.85 \% \mathrm{C}, 4.72 \% \mathrm{H}, 5.40 \% \mathrm{~N}$. (RS)-9: m.p. $222-225{ }^{\circ} \mathrm{C}$ (chloroform-hexanes).

\section{Study on Coordination of Metal Ions to Bispyridines 7-9}

NMR titrations. NMR titrations were carried out on a Varian Gemini 300 instrument at $298 \mathrm{~K}$. To a weighed amount of ca. $0.7 \mathrm{ml} 10-20 \mathrm{~mm}$ stock solution of bispyridine in $\mathrm{CDCl}_{3}-\mathrm{CD}_{3} \mathrm{CN}$ (1:1), a small amount (25-100 $\left.\mu \mathrm{l}\right)$ of 100-200 mm solution of zinc chloride in the same solvent mixture was added.

CD titrations. CD titrations were carried out on a Jasco J710 spectropolarimeter at $298 \mathrm{~K}$. To $10 \mu \mathrm{M}$ stock solution of bispyridine in THF ( $1 \mathrm{ml})$, a small amount (10-100 $\mu \mathrm{l})$ of 1-10 mM solution of silver triflate in the same solvent was added.

Crystal structure analysis. To a degassed solution of $7(23 \mathrm{mg})$ in dichloromethane $(2 \mathrm{ml})$ was slowly added a mixture of dichloromethane $(0.3 \mathrm{ml})$ and acetonitrile $(0.3 \mathrm{ml})$, and then a solution of $\left[\mathrm{Pd}(\mathrm{MeCN})_{2} \mathrm{Cl}_{2}\right](14 \mathrm{mg})$ in acetonitrile $(2 \mathrm{ml})$. The sample was stored in the dark place at room temperature for 5 days. Compound 17 (31 mg, 77\%) as orange crystals

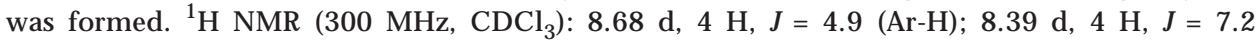
$(\mathrm{Ar}-\mathrm{H}) ; 8.36 \mathrm{dd}, 2 \mathrm{H}, \mathrm{J}=2.2$, $3.8(\mathrm{Ar}-\mathrm{H}) ; 7.81 \mathrm{ddd}, 2 \mathrm{H}, \mathrm{J}=1.6,7.7,8.2(\mathrm{Ar}-\mathrm{H}) ; 7.55-7.47 \mathrm{~m}$, $4 \mathrm{H}(\mathrm{Ar}-\mathrm{H}) ; 7.33-7.24 \mathrm{~m}, 4 \mathrm{H}(\mathrm{Ar}-\mathrm{H})$.

$\mathrm{X}$-ray data were collected at $\mathrm{T}=173(2) \mathrm{K}$ on a Stoe IPDS XRED32 diffractometer with graphite monochromatized MoK $\alpha$ radiation, $\lambda=0.71073 \AA$. The structure was solved by direct methods and refined by full-matrix least-squares techniques. The following computer programs were used: structure solution SHELXS97 ${ }^{26}$, refinement SHELXL97 ${ }^{27}$, molecular diagrams ORTEP. The non-hydrogen atoms were refined with anisotropic thermal parameters and hydrogens were included in idealized positions. Salient crystal data are as follows: $\mathrm{C}_{72} \mathrm{H}_{46} \mathrm{Cl}_{4} \mathrm{~N}_{6} \mathrm{Pd}_{2}$ (1349.75), triclinic, space group $\mathrm{C}-1, \mathrm{a}=8.7847(12), \mathrm{b}=8.9229(9), \mathrm{c}=$ 22.053(3) $\AA, \alpha=80.470(13), \beta=80.528(12), \gamma=63.379(11)^{\circ}, V=1516.0(3) \AA^{3}, Z=2, \rho_{\text {calc }}=$ $1.478 \mathrm{~g} \mathrm{~cm}^{-3}$. 17999 of reflections were collected in the range of $\theta$ from 2.61 to $27.98^{\circ}$. Final $R$ indices: $R_{1}=0.0295, w R_{2}=0.0705$; $R$ indices (all data): $R_{1}=0.0390, w R_{2}=0.0733$. Goodness-of-fit on $\mathrm{F}^{2}$ : 0.943 .

CCDC 647946 contains the supplementary crystallographic data for this paper. These data can be obtained free of charge via www.ccdc.cam.ac.uk/conts/retrieving.html (or from the Cambridge Crystallographic Data Centre, 12, Union Road, Cambridge, CB2 1EZ, UK; fax: +44 1223 336033; or deposit@ccdc.cam.ac.uk).

The authors are thankful to Prof. O. C. Kappe (University of Graz) for co-operation in application of microwave irradiation to cross-coupling reactions and to $\mathrm{Dr} \mathrm{M}$. Zabel (University of Regensburg) for $\mathrm{X}$-ray structure analysis. This work was supported by the Slovak Grant Agency for Science (grant No. $1 / 3568 / 06$ ) and by the Slovak Research and Development Agency (grant No. LPP-0210-06). 


\section{REFERENCES}

1. a) Connon S. J.: Angew. Chem. Int. Ed. 2006, 45, 3909; b) Maruoka K., Ooi T.: Chem. Rev. 2003, 103, 3013; c) Noyori R.: Asymmetric Catalysis in Organic Synthesis. Wiley, New York 1994; d) Rosini C., Franzini L., Raffaelli A., Salvadori P.: Synthesis 1992, 503; e) Pu L.: Chem. Rev. 1998, 98, 2405.

2. Ostroverkhov V., Petschek R. G., Singer K. D., Twieg R. J.: Chem. Phys. Lett. 2001, 340, 109.

3. a) Cram D. J.: Science 1988, 240, 760; b) Telfer S. G., Kuroda R.: Coord. Chem. Rev. 2003, 242, 33; and references therein.

4. Putala M.: Enantiomer 1999, 4, 243.

5. Kasák P., Putala M.: Tetrahedron Lett. 2004, 45, 791.

6. Kasák P., Mikláš R., Putala M.: J. Organomet. Chem. 2001, 637-639, 318.

7. a) Brath H., Dubovská M., Juríček M., Kasák P., Putala M.: Collect. Czech. Chem. Commun. 2004, 69, 1517; b) Kasák P., Brath H., Dubovská M., Juríček M., Putala M.: Tetrahedron Lett. 2004, 45, 791.

8. Desimoni G., Faita G., Jørgensen K. A.: Chem Rev. 2006, 106, 3561; and references therein.

9. Examples a) Pfaltz A.: Acc. Chem. Res. 1993, 26, 339; b) Müller D., Umbricht G., Weber B., Pfaltz A.: Helv. Chim. Acta 1991, 74, 232.

10. Tanner D.: Angew. Chem., Int. Ed. Engl. 1994, 33, 599.

11. Examples: a) Ito K., Katsuki T.: Tetrahedron Lett. 1993, 34, 2661; b) Malkov A. V., Bella M., Langer V., Kočovský P.: Org. Lett. 2000, 2, 3047.

12. Examples: a) Gant T. G., Noe M. C., Corey E. J.: Tetrahedron Lett. 1995, 36, 8745; b) Uozumi Y., Kyota H., Kishi E., Kitayama K., Hayashi T.: Tetrahedron: Asymmetry 1996, 7, 1603; c) Andrus M. B., Asgari D., Sclafani J. A.: J. Org. Chem. 1997, 62, 9365; d) Meyers A. I., Price A.: J. Org. Chem. 1998, 63, 412; e) Bai X. L., Kang C.-Q., Liu X.-D., Gao L.-X.: Tetrahedron: Asymmetry 2005, 16, 727.

13. a) Charmant J. P. H., Fallis I. A., Hunt N. J., Lloyd-Jones G. C., Murray M., Nowak T.: J. Chem. Soc., Dalton Trans. 2000, 1723; b) Charmant J. P. H., Hunt N. J., Lloyd-Jones G. C., Nowak T.: Collect. Czech. Chem. Commun. 2003, 68, 865.

14. Baidossi W., Schumann H., Blum J.: Tetrahedron 1996, 52, 8349.

15. a) An D. L., Nakano T., Orita A., Otera J.: Angew. Chem. Int. Ed. 2002, 41, 171; b) Orita A., An D. L., Nakano T., Yaruva J., Ma N., Otera J.: Chem. Eur. J. 2002, 8, 2005.

16. Krascsenicsová K., Walla P., Kasák P., Uray G., Kappe O. C., Putala M.: Chem. Commun. 2004, 2606.

17. King A. O., Okukado N., Negishi E.: J. Org. Chem. 1978, 43, 358.

18. a) Walla P., Kappe O. C.: Chem. Commun. 2004, 564; b) Kappe O. C.: Angew. Chem. Int. Ed. 2004, 43, 6250 .

19. Harada T., Nakanishi K.: Circular Dichroism Spectroscopy - Exciton Coupling in Organic Chemistry. Oxford University Press, Oxford 1983.

20. a) Proni G., Spada G. P., Lustenberger P., Welti R., Diederich F.: J. Org. Chem. 2000, 65, 5522; b) Zhou Y., Zhang D., Zhu L., Shuai Z., Zhu D.: J. Org. Chem. 2006, 71, 2123.

21. Kawano T., Shinomaru T., Ueda I.: Org. Lett. 2002, 4, 2545.

22. Komiya S.: Synthesis of Organometallic Compounds (A Practical Guide), p. 286. John Wiley \& Sons, New York 1997.

23. Vondenhof M., Mattay J.: Tetrahedron Lett. 1990, 31, 985. 
24. Brown K. J., Berry M. S., Murdoch J. R.: J. Org. Chem. 1985, 50, 4345.

25. Foxman B. M., Rosenblum M., Sokolov V., Khrushchova N.: Organometallics 1993, 12, 4805.

26. Sheldrick G. M.: SHELXS97: Program for Crystal Structure Solution. University of Göttingen, Göttingen 1997.

27. Sheldrick G. M.: SHELXL97. Program for Crystal Structure Refinement. University of Göttingen, Göttingen 1997. 